
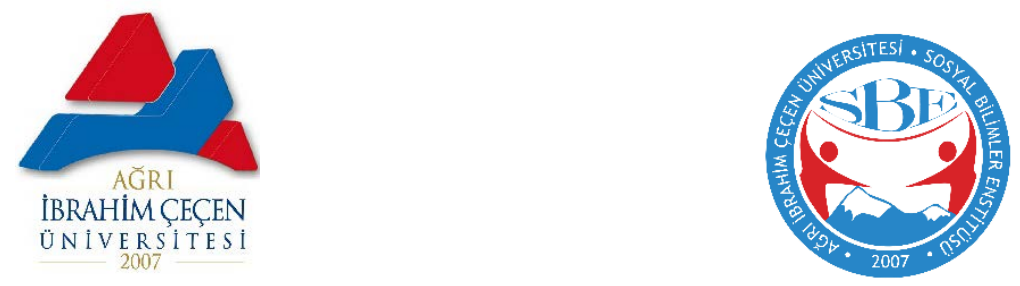

TIBBi-AROMATIK BiTKILERIN SATIN ALIMINDA BiREYLERIN BiLINÇ DÜZEYi (ERZURUM MERKEZ iLÇELERI ÖRNEĞi)

Awareness Level of Individuals in Purchasing Medical-Aromatic Plants (The Case of Erzurum Provence Counties)

\title{
Rüveyda YüZBAŞıĞLu
}

Dr. Öğr. Üyesi, Gaziosmanpaşa Üniversitesi, Ziraat Fakültesi Tarım Ekonomisi Bölümü ruveyda.kiziloglu@gop.edu.tr

https://orcid.org/ 0000-0002-6520-0543

\section{Semiha KIZILOĞLU}

Prof. Dr., Atatürk Üniversitesi, Ziraat Fakültesi Tarım Ekonomisi Bölümü ksemiha@atauni.edu.tr https://orcid.org/ 0000-0001-9610-2578

Ağrı ibrahim Çeçen Üniversitesi Sosyal Bilimler Enstitüsü Dergisi-Journal of Ağrı ibrahim Çeçen University Social Sciences Institute AiCUSBED 5/1 Nisan/April 2019 / Ağrı

ISSN: $\quad 2149-3006$

e-ISSN: 2149-4053

\begin{tabular}{|l|l|}
\hline Makale Türü-Article Types $:$ & Araştırma Makalesi \\
\hline Geliş Tarihi-Received Date $:$ & $11.03 .2019-$ \\
\hline Kabul Tarihi-Accepted Date $:$ & 18.04 .2019 \\
\hline Sayfa-Pages $: 119-132$ & do) 10.31463 /aicusbed.538184 \\
\hline
\end{tabular}

http://dergipark.gov.tr/aicusbed

This article was checked by

$\checkmark$ iThenticate 



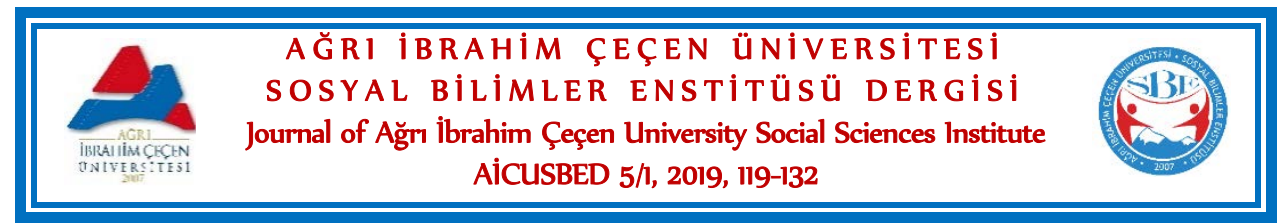

\section{TIBBI-AROMATIK BITKILERIN SATIN ALIMINDA BIREYLERIN BILINÇ DÜZEYi (ERZURUM MERKEZ iLÇELERi ÖRNEĞi) Awareness Level of Individuals in Purchasing Medical-Aromatic Plants} (The Case of Erzurum Provence Counties)

\section{Rüveyda YÜZBAŞIOĞLU} Semiha KIZILOĞLU

Öz

Tıbbi ve aromatik bitkiler; insanoğlunun daha sağlıkı bir yaşam sürmesi veya çeşitli hastalıklara karşı korumak ve iyileştirmek için kullanılan bitkilerdir. Dünya pazarlarında her geçen gün tıbbi ve aromatik bitkilere olan talep giderek artmaktadır. Bu çalışmada, Erzurum ili merkez ilçelerinde (Aziziye, Palandöken ve Yakutiye) kentsel alanda yaşayan bireylerin tıbbi ve aromatik bitkileri satın almadaki bilinç düzeyinin belirlenmesi amaçlanmıştır. Araştırmada, oransal örnekleme yöntemi kullanılarak 272 birey belirlenmiş ve örnek hacmi homojen olarak ilçelere dağıtılarak veriler anket yolu ile toplanmıştır.

Araştırma kapsamın görüşülen bireylerin ortalama yaşı 35.04, \%54.04'ü erkek, \%76.10'u evli ve 2,572.72 TL/ay geliri olduğu belirlenmiştir.

Bireylerin tıbbi aromatik bitkileri satın almada dikkat ettikleri 10 özellik, faktör analizi sonucu iki faktör halinde özetlenmiştir.

Araştırmada bireylerin tıbbi aromatik ürünleri satın almasını etkileyen faktörleri, binary logit analiz ile belirlenmiş ve analiz sonucuna göre; \%1 önem seviyesinde bireylerin tıbbi aromatik ürünleri satın almasını, satın alım yerleri olan aktarlar ve eczaneler pozitif yönlü etkilediği belirlenmiştir. Yani bireylerin bilinçli olarak tıbbi aromatik bitkiyi satın almasını satın alım yerleri ve mevsimsel tüketim istatistiki olarak pozitif yönde etkilediği belirlenmiştir.

Anahtar Kelimeler: Binary Logit Analizi, Faktör Analizi, Tıbbi Aromatik Bitkiler, Satın Alma Abstract

Medicinal and aromatic plants are used as medicines to prevent diseases, maintain health, or improve diseases. Demand for these plants in world markets is increasing every other day. This study aimed to determine the medicinal and aromatic plant level of consciousness at purchase of individuals living in the urban areas in the central counties of Erzurum city (Aziziye, Palandöken, and Yakutiye). In the study, 272 individuals were determined by using proportional sampling method and the sample volume was homogeneously distributed to the districts. The data of the study were collected through a questionnaire. The mean age of the interviewed individuals was found to be $35.04,54.04 \%$ of them were male, $76.10 \%$ of them were married, and they had income of 2,572.72 TL/month. 10 factors that individuals have taken into consideration in purchasing medicinal aromatic plants are summarized as two factors as a result of the factor analysis. Factors that enable individuals to purchase medicinal aromatic products in the study are the results of binary logit 
analysis; At the $1 \%$ significance level, the advantages of buying places for medicinal aromatic products of individuals, pharmacies and positively affected.

Keywords: Binary Logit Analysis, Factor Analysis, Medical Aromatic Plants, Purchasing

Giriş

İnsanoğlu varlığını devam ettirmesi için gerekli beslenme ihtiyacını çoğunlukla bitkisel ürünlerden karşılamaktadır. Bitkiler karbonhidrat, protein, yağ, mineral madde ve vitamin gibi büyük bir hazinedir. Bitkiler beslenme ihtiyacını karşılamanın yanında başta ilaç sanayi olmak üzere, gıda, kimya, kozmetik ve zirai mücadele gibi sektörler de önemli bir yeri vardır (Gölükçü ve ark., 2012; Toker ve ark., 2016).

Ayrıca tıbbi ve aromatik bitkilerin tüketilmesinin nedeni olarak, daha sağlıklı bir yaşam veya çeşitli hastalıklardan koruması ya da iyileştirmesi gösterilebilir. Bunun yanı sıra en çok gıda sektöründe kullanılan tıbbi ve aromatik bitkiler çeşitli sebeplerle de (beslenme, ilaç, kozmetik, vücut bakımı, tütsü veya dini törenler gibi) kullanılmaktadır (Güler ve ark., 2015; Toker ve ark., 2016).

Dünyada yaklaşı olarak 422.000 bitki türü bulunmakta olup, bunlardan 52.885'i tıbbi bitkilerdir. Türkiye'de ise 9.222 bitki türü olup, bunlardan yaklaşık 500 tanesi (\%5) tıbbi bitkiler grubunda yer almaktadır (Schippman ve ark., 2002; Faydalığlu ve Sürücü, 2011; Gül ve Çelik, 2016).

Türkiye'de tıbbi ve aromatik bitkiler arasında yaygın olarak kimyon, anason, kekik, çemen, haşhaş, rezene, nane ve kişnişin tarımı yapılmaktadır. Defne, ıhlamur, adaçayı, biberiye, kuşburnu gibi bitkiler ise doğadan toplanmakta olup, ağırlıklı olarak Ege, Marmara, Akdeniz, Doğu Karadeniz ve Güneydoğu Anadolu Bölgelerinden toplanmaktadırlar (Bayram ve ark., 2010; Gül ve Çelik, 2016).

Son yıllarda sağlıklı beslenemeye karşı ilginin artması koruyucu beslenme ve bununla birlikte doğal çözüm arayışları ilgili araştırmaların da artmasına neden olmuştur. Literatür incelendiğinde yurt içi ya da yurt dışında tüketicilerin tıbbi aromatik bitkilere karşı davranışları ya da aktarlardan satın alma-satımı ile ilgili detaylı araştırmalarla karşılaşılmıştır (Demircioğlu ve ark., 2007; Dicle, 2010; Faydalığlu ve Sürücü, 2011; Arya ve ark., 2012; Çelik, 2014; Kökçü ve ark., 2015; Adıgüzel ve Kızılaslan, 2016; Akbulut ve Özkan, 2016; Demirçivi ve Altaş, 2016; Kocabaş ve Gedik, 2016; Yüzbaşığlu ve Ataoğlu, 2018). Ancak son zamanlarda önemi artan tıbbi aromatik bitkiler üzerine yapılan araştırmalarda tüketicilerin satın alma davranışları ve onu etkileyen faktörlerin istatistiki olarak incelenmesi yapılmadı̆̆ı belirlenmiş ve literatüre ışık tutması amacıyla böyle bir araştırma yapılması amaçlanmıştır.

İnsanlığın bu kadar hayatına girmiş olan tıbbi aromatik bitkilerin tüketiminin yanında satın alma bilinç durumu ve güvenilir tüketim için satın alma da bilinç seviyesi de önemli olduğu tespitini ortaya koyabilmek için Erzurum ilinde bu araştırma yapılmıştır.

\footnotetext{
http://dergipark.gov.tr/aicusbed 5/1 Nisan / April 2019
} 


\section{Materyal ve Yöntem \\ Materyal}

Erzurum ili merkez ilçelerinde kentsel alanda bulunan bireylerle yüz yüze görüşülerek bu araştırmanın ana materyali elde edilmiştir.

\section{Verilerin Toplanması Aşamasında İzlenen Yöntem}

Toplam popülasyonu en iyi düzeyde temsil edilecek örneklem sayısının belirlenmesinde oransal yaklaşımdan yararlanılmıştır.

$\mathbf{n}=\frac{\mathbf{N}_{\mathbf{p}}(\mathbf{1}-\mathbf{p})}{(\mathbf{N}-\mathbf{1}) \mathbf{d}^{2}+\mathbf{p}(\mathbf{1}-\mathbf{p})}$

$\mathrm{n}=$ örnek büyüklüğü,

$\mathrm{N}=$ populasyon büyüklüğü,

$\mathrm{p}=$ tahmin oranı (0.5 maksimum örnek büyüklüğü için),

$\mathrm{d}^{2}=$ olayın görülme sıklı̆̆ına göre yapılma sıklı̆̆ (maksimum örnek hacmine ulaşmak için \%90 güven aralığında çizelge değeri 1.65 ve $\% 5$ hata payı ile). Ana kitleyi oluşturan bireylerin özellikleri başlangıçta bilinmediği için, örnek hacmini maksimum kılacak şekilde $\mathrm{p}=0.5$ olarak alınmış ve örnek hacmi 272 birey olarak bulunmuştur. Görüşülecek bireylerin sayısının belirlenmesinde, yerleşim birimlerinin toplam popülasyon içindeki payları esas alınmış (Kızıloğlu ve Kızılaslan, 2013) ve örneğe alınan bireyler tesadüfi olarak belirlenmiştir.

Çizelge l'de Erzurum büyükşehrinin merkeze bağlı üç ilçesinin nüfusu, toplamdaki oranı ve örnek hacmindeki dağılımı verilmiştir. Merkez ilçelerin toplamı 417.385 olarak belirlenmiş ve bu oran içinde merkez ilçelerin nüfuslarına göre oranları ortaya konulmuştur. Oransal örnekleme ile belirlenen sayı bu oranlar doğrultusunda homojen bir dağıtım yapılarak ilçelerdeki örnek hacmi belirlenmiştir.

Çizelge 1. Erzurum ili Nüfusu (2016)

\begin{tabular}{|l|c|c|c|}
\hline & Nüfus (N) & Örnek Hacmi (n) & Oran (\%) \\
\hline Aziziye & 57.092 & 37 & 13.68 \\
\hline Palandöken & 168.430 & 110 & 40.35 \\
\hline Yakutiye & 191.863 & 125 & 45.97 \\
\hline Erzurum (Merkez) & 417.385 & 272 & 100.00 \\
\hline
\end{tabular}

Verilerin Analizi Aşamasında İzlenen Yöntem

$\mathrm{Bu}$ araştırmada Erzurum ili merkez ilçelerindeki bireylerin tıbbi aromatik bitkileri satın almada dikkat ettikleri özellikleri (benzer çalışmalardan yararlanılarak ölçekler belirlenmiştir) belirlemek üzere $5^{\prime}$ li dereceleme ölçeğinde (Ölçekteki 1 "kesinlikle katılmıyorum", 2 “katılmıyorum”, 3 “kararsızım”, 4 "katılıyorum”, 5 "kesinlikle katılıyorum" olarak alınmıştır ) kullanılııştır. Satın alımında dikkat edilen kriterleri daha az faktör yüküne ayırmak için faktör analizi uygulanmıştır. Faktör analizi, değişkenler arasındaki ilişkilere dayanarak verilerin daha anlamlı ve özet bir biçimde sunulmasını sağlayan birçok değişkenli istatistiksel analiz türüdür ((Ness, 2000; Kurtuluş, 2004; Tekin, 2007; Karpati ve Szakal, 2009; Kızıloğlu ve

$$
\text { http://dergipark.gov.tr/aicusbed 5/1 Nisan / April } 2019
$$


ark., 2013). Bu analizin temel amacı, orijinal değişkenler arasındaki ilişkiyi en az bilgi kaybıyla bir grup faktör ile açıklayarak her bir faktörü teker teker yorumlamaktır. Kısaca faktör analizi, özgün bilgiyi olabildiğince koruyarak daha az veri ile çalışmayı mümkün kılmaktadır. Kişilerin bir konu ile ilgili davranışını tek bir soruyla ölçmek çoğu zaman mümkün olmamaktadır. Bu davranışı etkileyen birçok faktörün birbiriyle yakın bağlantısı vardır. Faktör analizinin amacı bilgi kaybını olabildiğince azaltarak bu yakın faktörleri bir araya getirerek daha az faktörle çalı̧şmaya imkan sağlamaktadır (Ness, 2000; Kızıloğlu ve ark., 2013).

Araştırmada değişkenlerin özetlenmesi faktör analizi yardımı ile yapılmıştır ve gruplandırılan bu faktörlerin her biri LOGiT analizinde birer açıklayıcı değişken olarak analize alınmıştır (Dölekoğlu ve Yurdakul, 2004).

Araştırmada bireylerin tıbbi aromatik ürünleri satın almayı etkileyen faktörleri binary logit analizi yardımı ile belirlenmesi amaçlanmıştır. Modelin bağımlı değişkeni olan bilinçli (sürekli ve çoğu zaman alanlar) bireyler ve bilinç seviyesi düşük olan (çok nadir ve almayan) bireyler belirlenmiştir.

Lojistik modelde yer alan bazı değişkenler, kategoriler arası farklılıkları olasılık oranları olarak elde edilebilmek üzere kategorik değişkene çevrilmiştir. Bağımlı değişken ile ilişkilendirilmesi yani açıklaması daha kolay ya da anlaşıır olması için açıklayıcı değişkenler kukla değişken halinde modele alınmış ve tahmin edilen olaslık değerleri 0 ile 1 olarak kodlanmıştır.

Modele açıklayıcı değişken olarak; bireylerin yaşı (sürekli değişken), cinsiyet (kadın ise 0 , erkek ise 1 olarak kodlanmıştır), medeni durum (bekar ise 0 , evli ise 1 olarak kodlanmıştır), eğitim durumu (lise ve lise altı ise 0 , lise üstü ise 1 olarak kodlanmıştır), eşinin eğitim durumu lise ve lise altı ise 0 , lise üstü ise 1 olarak kodlanmıştır, eşinin yaşı (sürekli değişken), eşinin çalışma durumu (çalışmıyorsa veya bekar ise 0 , çalısısyorsa ise 1 olarak kodlanmıştır), bireylerin aylık gelirleri (sürekli değişken), aktardan satın alma durumu (satın almıyorsa 0, satın alıyor ise 1 olarak kodlanmışır), eczaneden satın alma durumu (satın almıyorsa 0 , satın alıyor ise 1 olarak kodlanmıştır), toptancıdan satın alma durumu (satın almıyorsa 0 , satın alıyor ise 1 olarak kodlanmıştır), kendinin toplama durumu (toplamıyor ise 0 , topluyor ise 1 olarak kodlanmıştır), mevsimin etkisinin olma durumu (satın alırken mevsimin etkisi yok ise 0 , var ise 1), ürünün satın almadan önceki durumu (faktör 1, sürekli değişken) ve satın almadaki durumu (faktör 2, sürekli değişken) dahil edilmiştir.

\section{Bulgular ve Tartışma \\ Bireylerin Genel Özellikleri}

Araştırma kapsamında görüşülen bireylerin bazı sosyo-ekonomik ve demografik özellikleri Çizelge 2'de incelenmiştir. Bireylerin \%45.96'sı kadın, \%54.04'ü erkektir. Bireylerin \%76.10'u evli ve \%46.32'sinin eşleri çalışmaktadır (Çizelge 2). Bireylerin eğitim durumları incelendiğinde ise yarısından fazlasının (\%63.24) lise ve lise altı eğitim gördükleri ve eşlerinin de benzer şekilde \%80.15'nin lise ve altı eğitim aldıkları belirlenmiştir. Görüşülen bireylerin ortalama

http://dergipark.gov.tr/aicusbed 5/1 Nisan / April 2019 
yaşı 35.04, eşlerinin yaş ortalaması ise 28.66 olarak bulunmuştur. Bireylerin ortalama aylık geliri $2.57272 \mathrm{TL} /$ ay olarak hesaplanmıştır.

Çizelge 2'den de anlaşılacağı üzere Erzurum ilindeki bireylerin yarısından fazlasının (\%57.72) tıbbi aromatik bitki tüketiminde mevsimsel bir etkisinin olmadığı görünmektedir. Benzer olarak da Türkiye'nin en batısında bulunan İzmir ilinde yapılan araştırmada (Dicle, 2010) tüketicilerin mevsimsel olarak baharat tercih etmediği sonucuna varılmıştır. Ancak Çelik, (2014) Konya ilindeki Tıbbi ve aromatik aktarlarıyla yaptığı çalışmasında en fazla (\%36.7) kışın satış yaptığı sonucunu bulmuştur. Ancak araştırma kapsamında görüşülen bireylerin mevsiminde kendinin toplamasını tercih etmesi ihtiyacı oldukça satın almayı tercih etmesi mevsimsel olarak satın almada bir etkisinin olmayacağı sonucunu doğurabilir.

Çizelge 2. Bireylerin Genel Özellikleri ve Bazı İstatistiki Sonuçlar

\begin{tabular}{|c|c|c|c|c|c|}
\hline \multicolumn{2}{|c|}{ Gruplar ve Açıklaması } & Frekans & $\%$ & Ortalama & Standart \\
\hline \multirow[b]{2}{*}{$\begin{array}{l}\text { Bağımlı Değişken } \\
(\mathbf{Y})\end{array}$} & $\begin{array}{l}\text { Bilinçli (sürekli ve çoğu } \\
\text { zaman alanlar) bireyler:l }\end{array}$ & 150 & 55.15 & & \multirow[b]{2}{*}{0.498} \\
\hline & $\begin{array}{l}\text { Bilinç seviyesi düşük } \\
\text { olan (çok nadir veya } \\
\text { almayan) } \\
: 0\end{array}$ & 122 & 44.85 & & \\
\hline \multicolumn{4}{|l|}{ Yaş (YAS) } & 35.04 & \\
\hline \multicolumn{4}{|l|}{ Gelir (ay/TL) (GELIR) } & 2.57272 & \\
\hline \multirow{2}{*}{ Cinsiyet (CINSIYET) } & Kadın:0 & 125 & 45.96 & & \multirow{2}{*}{0.499} \\
\hline & Erkek:l & 147 & 54.04 & & \\
\hline \multirow{2}{*}{$\begin{array}{l}\text { Medeni Durum } \\
\text { (MD) }\end{array}$} & Bekar:0 & 65 & 23.90 & & \multirow{2}{*}{0.427} \\
\hline & Evli:l & 207 & 76.10 & & \\
\hline \multirow{2}{*}{$\begin{array}{l}\text { Eğitim Durumu (ED } \\
\text { ) }\end{array}$} & $\begin{array}{l}\text { Lise ve lise altı Mezunu } \\
\text { Olanlar:0 }\end{array}$ & 172 & 63.24 & & \multirow{2}{*}{0.483} \\
\hline & $\begin{array}{l}\text { Lise üstü Mezunu } \\
\text { Olanlar:I }\end{array}$ & 100 & 36.76 & & \\
\hline \multirow{2}{*}{$\begin{array}{l}\text { Eşinin Eğitim } \\
\text { Durumu (ESED) }\end{array}$} & $\begin{array}{l}\text { Lise ve lise altı Mezunu } \\
\text { Olanlar:0 }\end{array}$ & 218 & 80.15 & & \multirow{2}{*}{0.399} \\
\hline & $\begin{array}{l}\text { Lise üstü Mezunu } \\
\text { Olanlar:I }\end{array}$ & 54 & 19.85 & & \\
\hline \multicolumn{4}{|l|}{ Eşinin Yaşı (ESYAS) } & 28.66 & \\
\hline \multirow{2}{*}{$\begin{array}{l}\text { Eşinin Çalışma } \\
\text { Durumu (ESCALisM) }\end{array}$} & $\begin{array}{l}\text { Çalışmıyor (Emekli, îşsiz, } \\
\text { İş arıyor, öğrenci):0 }\end{array}$ & 146 & 53.68 & & \multirow[t]{2}{*}{0.499} \\
\hline & Çalışıyor:1 & 126 & 46.32 & & \\
\hline \multirow{2}{*}{$\begin{array}{l}\text { Aktardan satın alma } \\
\text { durumu durum } \\
\text { (AKTAR) }\end{array}$} & Satın almıyorsa:0 & 206 & 75.74 & & \multirow[b]{2}{*}{0.429} \\
\hline & Satın alıyor ise:l & 66 & 24.26 & & \\
\hline \multirow{2}{*}{$\begin{array}{l}\text { Eczaneden satın } \\
\text { alma durumu }\end{array}$} & Satın almıyorsa:0 & 175 & 64.34 & & \multirow{2}{*}{0.479} \\
\hline & Satın alıyor ise:l & 97 & 35.66 & & \\
\hline
\end{tabular}


Rüveyda YÜZBAŞIOĞLU - Semiha KIZILOĞLU

\begin{tabular}{|c|c|c|c|c|}
\hline (ECZANE) & & & & \\
\hline \multirow{2}{*}{$\begin{array}{l}\text { Toptancidan satın } \\
\text { alma durumu } \\
\text { (TOPTANCi) }\end{array}$} & Satın almıyorsa:0 & 215 & 79.04 & \multirow[b]{2}{*}{0.408} \\
\hline & Satın alıyor ise:l & 57 & 20.96 & \\
\hline \multirow{2}{*}{$\begin{array}{l}\text { Kendinin toplama } \\
\text { durumu (KENDi) }\end{array}$} & Toplamıyor ise:0 & 15 & 5.51 & \multirow{2}{*}{0.229} \\
\hline & Topluyor ise:1 & 257 & 94.49 & \\
\hline \multirow{2}{*}{$\begin{array}{l}\text { Mevsimin etkisinin } \\
\text { olma durumu } \\
\text { (MEVsiM) }\end{array}$} & $\begin{array}{l}\text { Satın alırken mevsimin } \\
\text { etkisi yok ise:0 }\end{array}$ & 157 & 57.72 & \multirow[t]{2}{*}{0.495} \\
\hline & Var ise:1 & 115 & 42.28 & \\
\hline
\end{tabular}

Bireylerin Tıbbi Aromatik Bitki Tüketimi ve Satın Alma Durumları

Bireylerin tükettiği tıbbi aromatik bitkiler sırasıyla Çizelge 3'de verilmiş aynı zamanda aylık satın alım miktarları ve bitkilerin birim fiyatları da verilmiştir. Erzurum ilindeki bireylerin en fazla (\%85.29) tüketmeyi tercih ettiği tıbbi aromatik bitki; ayda ortalama yarım kilo ve kilosunu 12.33 TL'ye aldıkları kırmızı pul biberdir. Bireylerin tüketmeyi en fazla tercih ettiği kırmızı pul biberi sırasıyla, nane (\%77.94), sarımsak (\%58.46), kekik (\%40.07), reyhan (\%32.35) ve thlamur (\%22.06) takip etmektedir. Bireylerin aylık tüketim miktarı olarak en fazla tükettiği bitki sarımsak ( $0.54 \mathrm{~kg} / \mathrm{ay})$ olduğu Çizelge 3 'den anlaşılmaktadır. İzmir ilindeki tüketiciler ise en fazla karabiber ve kimyonu tükettiği Dicle (2010), yaptığı araştırma ile ortaya koymuştur. Yine İzmir ilinde yapılan Karademir ve Öztürk, 2004 yılında aktarların en çok sattığı tıbbi aromatik ürün olarak, adaçayı, ıhlamur, nane, kekik ve isırgan olduğunu ortaya koymuştur. Akbulut ve Özkan, 2016 yılında Kahramanmaraş ilinde yaptıkları araştırmalarında aktarları en fazla sattığı, tüketicilerin en fazla satın aldığı tıbbi aromatik baharat türü olarak, nane, kekik ve ıhlamur olarak belirlemişlerdir. Demircioğlu ve ark., 2007 yılında Ankara merkez ilçede kadınların baharat kullanımı üzerine yaptıkları araştırmalarında kadınların \%83.5'i kırmızı pul biber kullandıkları belirlenmiştir.

Çizelge 3. Bireylerin Tüketmeyi Tercih Ettikleri Tıbbi Aromatik Bitkiler, Tüketim Miktarları ve Birim Fiyatları

\begin{tabular}{|l|r|r|r|r|l|r|r|r|r|}
\hline $\begin{array}{c}\text { Kullanılan } \\
\text { Bitkiler }\end{array}$ & F & \% & Kg/ay & TL & Kullanılan Bitkiler & F & \% & Kg/ay & TL \\
\hline Kırmızı Pul Biber & 232 & 85.29 & 0.528 & 12.331 & Kişniş & 8 & 2.94 & 0.021 & 0.404 \\
\hline Nane & 212 & 77.94 & 0.176 & 3.681 & Avokado Yaprağı & 8 & 2.94 & 0.017 & 2.059 \\
\hline Sarımsak & 159 & 58.46 & 0.536 & 15.562 & Yaban Mersini & 8 & 2.94 & 0.058 & 9.559 \\
\hline Kekik & 109 & 40.07 & 0.054 & 1.736 & Ekinezya & 7 & 2.57 & 0.064 & 4.779 \\
\hline Reyhan & 88 & 32.35 & 0.069 & 1.202 & Kantaron & 6 & 2.21 & 0.063 & 3.125 \\
\hline lhlamur & 62 & 22.79 & 0.017 & 6.967 & Nar Çiçeği & 6 & 2.21 & 0.048 & 1.875 \\
\hline Adaçayı & 60 & 22.06 & 0.041 & 1.119 & Fesleğen & 6 & 2.21 & 0.052 & 0.846 \\
\hline Dereotu & 54 & 19.85 & 0.396 & 1.389 & Melisa(Limon Otu) & 5 & 1.84 & 0.033 & 0.735 \\
\hline Çörek Otu & 52 & 19.12 & 0.072 & 1.265 & Keten Tohumu & 5 & 1.84 & 0.033 & 0.846 \\
\hline Kuşburnu & 38 & 13.97 & 0.491 & 3.668 & Gülhatmi & 4 & 1.47 & 0.006 & 0.625 \\
\hline Papatya & 36 & 13.24 & 0.809 & 2.908 & Hindiba & 3 & 1.10 & 0 & 0 \\
\hline
\end{tabular}

http://dergipark.gov.tr/aicusbed 5/1 Nisan / April 2019 
Tıbbi-Aromatik Bitkilerin Satın Alımında Bireylerin Bilinç Düzeyi (Erzurum Merkez ilçeleri Örneği)

\begin{tabular}{|l|r|r|r|r|l|r|r|r|r|} 
Melengiç & 28 & 10.29 & 0.145 & 3.971 & Sütleğen & 3 & 1.10 & 0 & 0 \\
\hline Ebegümeci & 27 & 9.93 & 0.746 & 1.049 & Efelek & 2 & 0.74 & 0 & 0 \\
\hline Bögürtlen & 26 & 9.56 & 0.241 & 2.222 & Mercanköşk & 2 & 0.74 & 0 & 0 \\
\hline lsırgan & 21 & 7.72 & 0.221 & 5.926 & Civanperçemi & 2 & 0.74 & 0 & 0 \\
\hline Keçiboynuzu & 21 & 7.72 & 0.154 & 5.257 & Oğul Otu & 2 & 0.74 & 0 & 0 \\
\hline Salep & 19 & 6.99 & 0.046 & 3.750 & Zerdeçal & 2 & 0.74 & 0 & 0 \\
\hline Biberiye & 12 & 4.41 & 0.009 & 1.697 & Kebere & 2 & 0.74 & 0.004 & 2.941 \\
\hline Zencefil & 10 & 3.68 & 0.027 & 0.125 & & & & & \\
\hline
\end{tabular}

Çizelge 4'de bireylerin tıbbi aromatik bitkileri en çok hangi sıklıkla aldığı verilmiş̧ir. Bireylerin \%34.19'luk oranla bittikçe almayı tercih ederken, \%17.28'si ayda bir, \%14.71'i ayda iki üç kere satın almayı, \%8.82'si yılda iki kere ve \%6.25'i yılda bir kere almayı tercih ettiği Çizelge 4'den anlaşılmaktadır. Bireylerin \%9.93 hiç satın almayıp mevsiminde kendilerinin topladıklarını tüketmeyi tercih ettikleri belirlenmiştir. Bireylerin tıbbi aromatik ürün satın almamadaki nedenleri incelendiğinde, en önemlisi olarak; Kaliteli ürünler olduğuna inanmamaları (\%73.53), lezzetli olmaması (\%64.34) ve taze olduğuna inanmamaları (\%39.71) olarak gözlenmiştir. İzmir ilinde Dicle (2010) yaptığı araştırmada da tüketicilerin tıbbi aromatik ürün almada bu araştırma ile paralel sonuçları bulmuştur. Örneğin ürünün pahalı olması (\%3.58), kaliteli olmaması (\%3.55) ve nerden geldiği belli olmaması (\%3.44) gibi nedenlerden dolayı tıbbi aromatik ürünü satın almayı tercih etmediğini ortaya koymuştur.

Çizelge 4. Bireylerin Tıbbi Aromatik Bitki Satın Alım Sıklı̆̆ı

\begin{tabular}{|l|c|c|}
\hline \multicolumn{1}{|c|}{ Satın Alım Sıklı̆ı } & F & \% \\
\hline Sadece Kendi Toplayan & 27 & 9.93 \\
\hline Bittikçe & 93 & 34.19 \\
\hline Hafta Da Bir & 24 & 8.82 \\
\hline Ayda Bir & 47 & 17.28 \\
\hline 2-3 Ayda Bir & 40 & 14.71 \\
\hline 5-6 Ayda Bir & 24 & 8.82 \\
\hline Yılda Bir & 17 & 6.25 \\
\hline
\end{tabular}

Bireylerin tıbbi aromatik bitkiyi tedarik edinme şsekli sorulduğunda \%94.49'ü satın almadan önce kendi mevsiminde toplamayı birinci sırada tercih ettiği; satın alım yeri olarak en fazla eczane ve marketi (\%35.66) tercih ettiği belirlenmiştir (Çizelge 5). Dikkat edilecek bir olay; bireylerin \%5.15'i son zamanlar da en çok kullanılan internet ortamı ile tıbbi aromatik bitkileri tedarik etmesidir. $\mathrm{Bu}$ da araştırma kapsamında görüşülen bireylerin ve eşlerinin genç yaş grubuna girmesi ve çalışma oranının fazla olmasından dolayı olabilir. Dicle, (2010) araştırmasında İzmir ilindeki tüketicilerin tıbbi ve aromatik bitkileri satın alım sıklı̆̆ının en yüksek aktardan olduğu belirlemiştir. Ancak bu araştırma kapsamında bireylerin tıbbi aromatik bitkileri temin etmelerinde aktarları 3. sıra da tercih ettiği Çizelge 5'de görülmektedir. Güven, kalite, ürün çeşitliliği gibi sebeplerden dolayı

$$
\text { http://dergipark.gov.tr/aicusbed 5/1 Nisan / April } 2019
$$


Türkiye'nin batı kesimlerinde aktarların tercih edilme oranı Doğu Anadolu'ya göre daha yüksek olduğu araştırma sonuçlarına göre söylenebilir.

Çizelge 5. Bireylerin Tıbbi Aromatik Bitki Satın Almayı Tercih Ettikleri Yerler

\begin{tabular}{|l|c|c|}
\hline \multicolumn{1}{|c|}{ Satın Alım Yeri } & F & \% \\
\hline Aktar & 66 & 24.26 \\
\hline Eczane & 97 & 35.66 \\
\hline Market & 97 & 35.66 \\
\hline Toptancı & 57 & 20.96 \\
\hline İnternet & 14 & 5.15 \\
\hline Kendinin Topladığı & 257 & 94.49 \\
\hline
\end{tabular}

\section{Bireylerin Tıbbi Bitkileri Satın Almada Dikkat Ettikleri Hususlar}

Bireylerin tıbbi aromatik bitki satın alırken dikkat ettikleri özellikleri belirlemek üzere 5'li likert ölçeği kullanılmıştır. Dikkat edilen özellikler belirlenmek üzere 10 özellik kendi içlerinde gruplandırma yapılanabilir mi diye faktör analizi yapılmıştır. Analiz sonucunda 10 özellik; ürünün satın almadan önceki durumu ve satın almadaki durumu olmak adı altında 2 faktör altında toplanabileceği anlaşılmıştır.

Faktör analizinin kabulü için KMO testi sonucuna bakılır. Bu değerin 0.600'dan büyük olması modelin anlamlılı̆̆ın belirler çünkü bire yaklaştıkça modelin açıklayıcılı̆̆ı artmaktadır (Tabachnick ve Fidell, 1996; Kalaycı, 2010). Nitekim Çizelge 6'da göründüğü üzere araştırmanın model açıklayıcıllğı 0.817 olması örneklemin yüksek ve modelin kabulü anlamına gelmektedir (Field, 2000; Topçu, 2006; Keleş, 2007, Yılmaz, 2009; Kızıloğlu ve ark., 2013).

Ölçeğin güvenirliğini ortaya koymak amacıyla yapılan Cronbach Alpha güvenirlik katsayısı ise 0.89 olarak bulunmuştur. Buna göre ölçeğin güvenirliğinin oldukça yüksek olduğu söylenebilir.

10 başlık altında sıralanan bireylerin "tıbbi aromatik bitki satın alırken dikkat ettikleri özellikler", faktör analizinde özdeğer (eigen value) ve yamaç eğim grafiği (scree plot) incelemesi sonucunda 2 faktör altında toplanmıştır. ilk faktör toplam varyansın \%34.19'nu, ikinci faktör ise \%14.78'sini açıklarken, birikimli varyans, toplam varyansın \%48.98'ni açıkladığı görülmüştür.

Ziraat alanında yapılmış diğer çalşsmalarda elde edilen sonuçlar incelendiğinde; Çelik (2012)'nin çalışmasında KMO değeri 0.717 ve önemli faktör sayısı 5 bulunurken, faktörlerin varyansı açıklama oranı \%69.32elde edilmiştir. Çelik ve Tatlıyer (2016)'in faktör analizi çalışmasında 13 değişken 4 faktörle \%75.53'lik varyansı açıklama oranı ile belirlenebilmiştir. Kızıloğlu ve Kızılaslan (2015) bireylerin süt ve süt ürünleri satın alma yeri belirlerken dikkat ettikleri 16 özelliği 3 değişken halinde özetlemiş ve KMO değerini 0.884 olarak hesaplamıştır.

http://dergipark.gov.tr/aicusbed 5/1 Nisan / April 2019 
Çizelge 6. Bireylerin Tıbbi Aromatik Bitki Satın Alırken Dikkat Ettikleri Özellikler için KMO ve Barlett Testi

\begin{tabular}{|l|l|r|}
\hline Kaiser-Meyer-Olkin Testi & 0.817 \\
\hline \multirow{3}{*}{ Bartlett Testi } & Khi kare & 631.821 \\
\cline { 2 - 3 } & df & 45 \\
\cline { 2 - 3 } & Önem seviyesi & 0.000 \\
\hline
\end{tabular}

Aromatik bitki satın alırken dikkat ettikleri özellikler; ürünün satın almadan önceki durumu ve satın almadaki durumu başlıkları altında yani 10 değişkeni 2 faktör yükünde toplanabileceği Çizelge 7'den anlaşılmaktadır. ı. Faktör yükünde yani ürünün satın almadan önceki durumu başlı̆̆ı altında 7 değişkeni, satın almadaki durumu başlı̆ı̆ altında 3 değişkeni toplaya bilenebileceğini dönüşümlü faktör yükleri matrisi göstermiştir.

Çizelge 7. Bireylerin Tıbbi Aromatik Bitki Satın Alırken Dikkat Ettikleri Özellikler iç̧in Dönüşümlü Faktör Yükleri (Rotated Component Matrix)

\begin{tabular}{|l|c|c|}
\hline \multicolumn{3}{|c|}{ Faktör 1: ürünün satın almadan önceki durumu } \\
\hline Tedavi amaçlı & $\mathbf{0 . 8 2 5}$ & -0.107 \\
\hline Aracısız ulaşma & $\mathbf{0 . 7 3 8}$ & -0.083 \\
\hline Ambalaj & $\mathbf{0 . 7 0 6}$ & -0.018 \\
\hline Doğal ve güvenilir ürünler olması & $\mathbf{0 . 6 8 8}$ & 0.063 \\
\hline Hazırlama kolaylı̆ıı & $\mathbf{0 . 6 6 1}$ & -0.029 \\
\hline Ekonomik olması & $\mathbf{0 . 6 3 1}$ & 0.237 \\
\hline Fiyat & $\mathbf{0 . 5 2 0}$ & 0.023 \\
\hline & -0.287 & 0.714 \\
\hline Sağlı ve besin değeri & 0.038 & $\mathbf{0 . 6 7 6}$ \\
\hline Marka & 0.185 & 0.657 \\
\hline Yan etkileri &
\end{tabular}

\section{Bireylerin Tıbbi Aromatik Bitki Satın Almadaki Bilinç Düzeylerini Etkileyen Bazı Faktörler}

Bireylerin tıbbi aromatik bitki satın alımındaki bilinç düzeyini etkileyen bazı sosyo-demografik özellikler ve analiz sonucu Çizelge 8 'de verilmiştir. Tıbbi aromatik bitki satın alımındaki bilinç düzeyini etkilemesi olasılıklı olan değişkenler analize alınmış ve Binary Logit analizi sonucunda aktardan, eczaneden ve toptancıdan satın alma ve mevsimin etkisi tüketicilerin tıbbi aromatik ürün satın alımındaki bilinç düzeyi etkilemesi olası olduğu belirlenmiştir. 
Çizelge 8. Bireylerin Tıbbi Aromatik Bitki Satın Alımındaki ki Bilinç Düzeylerini Etkileyen Faktörlerin Binary Logit Analiz Sonucu

\% önem seviyesinde anlamlı bulunan aktardan, eczaneden ve toptancıdan satın alma ve mevsimin etkisi pozitif yönde bilinç düzeyini etkilemektedir.

Bilinçli olarak satın alma ile aktardan satın almayı tercih etme arasında pozitif bir ilişki olduğu Çizelge 8'de görülmektedir. Bir başka değiş ile aktardan tıbbi aromatik bitki satın almayı tercih etmedeki bir birimlik artış bilinçli satın almayı \%28 oranında artırmasına neden olması beklenmektedir.

Bireylerin gerek güven gerek kalite olsun eczanelerden satın almayı tercih etmesi bilinçli satın alma ile doğru ilişki olduğu analiz sonucunda istatistiki olaraktan ortaya konulmuştur. Yani bireylerin eczaneden tıbbi aromatik bitki satın almadaki bir birimlik artış bilinçli satın almayı \%48 gibi bir oranla artırması olası bir sonuç olduğu Çizelge 8 'de analiz sonucu ile ortaya konulmuştur.

Bireylerin toptancıdan tıbbi aromatik bitki almayı tercih etmesindeki bir birimlik artış bilinçli satın almayı \%33 oranında artmasına neden olabilir.

Bireylerin mevsimsel olarak Tıbbi aromatik ürün tüketmeyi tercih etmesindeki bir birimlik artış bilinçli satın almayı \%15 oranında etki yapması beklenmektedir. Başka bir ifade ile mevsimsel tüketime önem verenler önem vermeyenlere göre bir birimlik artışı, bilinçli satın almayı \%ı oranında pozitif yönlü etki yapması beklenmektedir.

\section{http://dergipark.gov.tr/aicusbed 5/1 Nisan / April 2019}




\section{Sonuç ve Öneriler}

Araştırma kapsamında görüşülen bireylerin ve eşlerinin yaş ortalaması itibariyle genç nüfus olduğu bireylerin çoğunun çalıştığı gözlenmiştir. Ayrıca bireylerin ortalama bir aylık gelirleri olduğu söylenebilir. Araştırmada tıbbi aromatik bitki satın alımında gelirin yanı sıra bireylerin eğitim durumu, bitkiyi satın alım yeri, satın alınırken dikkat edilen hususların etkisinin istatistiki olarak ortaya konulması hedeflenmiştir. Hedefler sonucunda satın almada genel olarak gelirleri ya da eğitim durumları arasında istatistiki olarak ilişki olmadığı gözlenmiştir. Tıbbi aromatik ürün satın almada bireylerin satın aldığı ürünleri daha çok sağlık amaçlı tükettiğini ifade etmektedir. Yani güncel ve git gide önemi artan tıbbi aromatik bitkilerin satın alınımını artırmak için (bilinçli bir satın alım için) satılan yerlerin daha önemli olduğu bu araştırma ile ortaya konulmuştur. Bu sonuç neticesinde ilgili kurum/kuruluşların daha sağlıklı ve hijyenik ürünler için tıbbi aromatik bitkilerin satılan yerleri daha sık ve dikkatli kontrollerin yapılmasını öneriline bilir. İnsanoğlunun temel ihtiyaçlarından olmasa da satın alma ihtiyaç piramittin de yerini almaktadır. Ancak satın alma bilinçli olarak yapılması sağlık yönünden özellikle konunun amacı olan tıbbi aromatik bitkilerin de önemi daha fazladır. Bu amaçla bu araştırmada Doğu Anadolu bölgesinin nüfus yoğunluğu bakımından en büyük üçüncü ili olan Erzurum ilindeki bireylerin tıbbi aromatik bitki satın alım bilinç düzeyi, satın alma davranışı ve bilinçli satın almayı etkileyen faktörlerin belirlenmeye çalışılmıştır.

Bireylerin en fazla tüketmeyi tercih ettiği baharat türünden kırmızı pul biberdir. Bireyler mevsiminde tüketeceği tıbbi aromatik bitkiyi kendi toplamayı tercih ederken, market ve eczanelerden de satın aldığı belirlenmiştir.

Bireylerin tıbbi aromatik bitkileri satın almada dikkat ettikleri faktörler, faktör analizine tabi tutulmuştur. Analiz sonucunda 10 özellik; ürünün satın almadan önceki durumu ve satın almadaki durumu olmak üzere 2 faktör altında toplanabileceği anlaşılmıştır. Bu 2 faktör yükleri Binary logit analizine açıklayıcı değişken olarak tabi tutulmuştur. Analiz sonucunda bireylerin \%55.15'i bilinçli olduğu tespit edilmiştir. Bireylerin tıbbi aromatik ürünleri satın alım yerlerinden aktarlar, eczaneler ve pozitif etkilediği belirlenmiştir. Yani bireylerin bilinçli olarak tıbbi aromatik bitkiyi satın almasını satın alım yerleri ve mevsimsel tüketim istatistiki olarak pozitif yönde etkilediği belirlenmiştir. Sonuç olarak bireylerin satın almasında satın alım yerlerinin pozitif bir ilişki olduğu istatistiki olarak ortaya konulmuştur. Satın alım davranı̧̧larında bireylerin satın alınan ürünlerin satış öncesi ve satış sırasındaki işlemlerde önemli başlık olduğu analiz sonucunda ortaya konulmuştur.

\section{Kaynaklar}

Adıgüzel, F. ve N.Kızılaslan, 2016. İstanbul ilinde tıbbi, aromatik ve baharat bitkileri satışı yapan aktarların yapısal özellikleri ve mevzuat hakkındaki görüşleri. Anadolu Tarım Bilim. Dergisi, 31, s:40-59.

\footnotetext{
http://dergipark.gov.tr/aicusbed 5/1 Nisan / April 2019
} 
Akbulut, S. ve Z.C. Özkan, 2016. Herbalist-Customer Profile in Medicinal and Aromatic Herbs Trade: A Case Study of Kahramanmaraş, Turkey. Kastamonu University Journal of Forestry Faculty, 16 (1), 246-252.

Arya, V., R. Thakur, S. Kumar ve S. Kumar, 2012. Consumer buying behaviour towards Ayurvedic medicines/products in Joginder nagar-A survey.Ayurpharm-International Journal of Ayurveda and Allied Sciences, 1(3), 60-64.

Bayram, E, S. Kırıcı S Tansı, G.Yılmaz, O .Arabacı, S. Kızıl ve D.Telci 2010. Tıbbi ve Aromatik Bitkiler Üretiminin Arttırılması Olanakları. Türkiye Ziraat Mühendisliği Vıl.Teknik Kongresi Bildiriler Kitabı , 11-15 Ocak, ANKARA, 437-456.

Çelik, Ş. 2012. Türkiye deki illerin Bitkisel Üretiminin Faktör Analizi ile İncelenmesi. Yüzüncü Yıl Üniversitesi Tarım Bilimleri dergisi, 22(2), 69-76.

Çelik, Ş. ve A.Tatliyer 2016. Ranking of provinces in Turkey according to numbers of animals through factor analysis. International Journal of Development Research, 6(2), 6620-6626.

Çelik, Y. 2014. Konya ilinde tıbbi ve aromatik bitki satışı yapan aktarların sosyoekonomik yapıları üzerine bir araştırma. Turkish journal of Agricultural and Natural Sciences, 1(3), 369-376.

Demircioğlu , Y., M. Yaman, ve 1. Şimşek, 2007. Kadınların Baharat Kullanım Alışkanlıkları Üzerine Bir Araştırma. TSK Koruyucu Hekimlik Bülteni, 6 (3), s:161-168.

Demirçivi, B.M. ve A. Altaş, 2016. Üniversite Öğrencilerinin Baharatlara ilişkin Bilgileri ve Tüketim Tercihleri: Aksaray Üniversitesinde Bir Uygulama. Journal of Tourism and Gastronomy Studies 4/4 s: 88-112.

Dicle, M. 2010. İzmir ili Bornova ilçesinde Tıbbı Bitkilere ilişkin Tüketici Davranışlarının Belirlenmesi Üzerine Bir Araştırma. Ege Üniversitesi Fen Bilimleri Enstitüsü (Yüksek Lisans Tezi)

Dölekoğlu, C. ve O.Yurdakul, 2004. Adana ilinde Hane Halkının Beslenme Düzeyleri ve Etkili Faktörlerin Logit Analizi ile Belirlenmesi. Akdeniz iiBF Dergisi, 8: 62-86.

Faydaoğlu, E. ve M.S. Sürücüoğlu, 2011. Geçmisten Günümüze Tıbbi ve Aromatik Bitkilerin Kullanılması ve Ekonomik Önemi. Kastamonu Üni., Orman Fakültesi Dergisi, 11 (1) s: $52-67$.

Field,A. 2000. Discovering Statistics Using SPSS for Windows. London: SAGE Publication.

Gölükçü, M., H.Tokgöz, R.Toker, M.A. Çelikyurt, ve S.Tuğrul Ay, 2012. Tıbbi ve Aromatik Bitki iş̧letmelerinin Yapısal Analizi, Erdem Ofset, Antalya, 88s.

Gül, A. ve A.D. Çelik 2016. Tıbbi ve Aromatik Bitki Yetiştiriciliği ve Dış Ticareti: Hatay ili Örneği. Mustafa Kemal Üniversitesi Ziraat Fakültesi Dergisi, 21 (2), s:227-235.

http://dergipark.gov.tr/aicusbed 5/1 Nisan / April 2019 
Güler, H.K., i.E. Dönmez ve S.A. Aksoy, 2015. Tıbbi ve Aromatik Bitkilerin Antibakteriyel Aktivitesi ve Tekstil Sektöründe Kullanımı. SDÜ Fen Dergisi, 10(2).

Kalaycı, Ş. 2010. SPSS Uygulamalı Çok Değişkenli ìstatistik Teknikleri. BRC Matbaacılık, Ankara.

Karademir, M. ve B. Öztürk, 2004. İmir aktarlarında halka sunulan bitkiler. 14. Bitkisel ilaç Hammaddeleri Toplantısı, 29-31.

Karpati, L. ve Z. Szakal, 2009. Marketing Characteristics of Tokaj Wine Specialities Based on Factor and Cluster Analyses. Applied Studies in Agribusiness and Commerce - APSTRACT Agroinform Publishing House, Budapest. p: 93102.

Keleş, C. 2007. Yeşil Pazarlama Tüketicilerin Yeşil Ürünleri Tüketme Davranışları ve Yeşil Ürünlerin Tüketiminde Kültürün Etkisi ile ilgili Bir Uygulama. Sosyal Bilimler Enstitüsü, i̇şletme ABD, (Yüksek Lisans Tezi).

Kızıloğlu, R. ve H. Kızılaslan, 2013. Consumer behaviors on food purchasing places: A case study of red meat consumption in Turkey, Research\&Reviews in Biosciences (RRBS), ISSN : 0974 - 7532, 7 (11), 453-459.

Kızıloğlu, R., H. Kızılaslan ve C.Gökçe, 2013. Gaziosmanpaşa Üniversitesi Ziraat Fakültesi Öğrencilerinin Yeşil Gıda Ürünleri Hakkındaki Bilgi, Görüş ve Tutumları Üzerine Araştırma. Gaziosmanpaşa Bilimsel Araştırma Dergisi, 6, 19-30.

Kızıloğlu, R. ve H. Kızılaslan, 2015. TR 83 Bölgesinde Süt ve Süt Ürünleri Tüketiminde Tüketici Davranışlarını Etkileyen Faktörler Ve Talebinin Belirlenmesi. Tarımsal Ekonomi ve Politika Geliştirme Enstitüsü TEPGE, Yayın No: 274, ISBN: 978-605-9175-52-4.

Kocabaş, Y.Z. ve O.Gedik, 2016. Kahramanmaraş il Merkezi Semt Pazarlarında Satılan Bitkiler Hakkında Etnobotanik Araştırmalar. ı̆̆dır Üni. Fen Bilimleri Enst. Der. / Iğdır Univ. J. Inst. Sci. \& Tech. 6(4) s: 41-50,

Kökçü, B., O. Esen ve i. Uysal, 2015. Medicinal plants sold in Çanakkale/Turkey city center herbalists. Biological Diversity and Conservation - 8 / 3 s:80-91.

Kurtuluş, K. 2004. Pazarlama Araştırmaları (Genişletilmiş 7. Baskı). Literatür Yayınları, Yayın No: 114, s:397-418, ìstanbul.

Ness, M. 2000. Multivariate Techniques in Marketing Research. Curso de Especializacion Postuniversitaria en Marketing Agroalimentario, CHIEAM, Spain.

Schippmann U., L.J. Leaman and A.B. Cunnigham, 2002. Impact of Cultivation and Gathering of Medicinal Plants on Biodiversity: Global Trends and 1ssues. 1213 October 2002. Inter-Departmental Working Group on Biological Diversity for Food and Agriculture, Rome.

Tabachnick, B.G. ve L.S. Fidell, 1996. Using multivariate statistics (3rd ed.). New York, USA: HarperCollins College Publishers. 
Tekin, V.N. 2007. SPSS Uygulamalı Bilimsel Pazarlama Araştırmaları. Seçkin Yayıncilık, Ankara.

Toker, R., M. Gölükcü ve H. Tokgöz, 2016. Tıbbi ve aromatik bitkilerin gıda sanayisinde kullanım alanları. (internet erişim: http://www.turktob.org.tr/dergi/makaleler/dergi15/54-59.pdf)

Topçu, Y. 2006. Süt Ürünlerinde Marka Rekabeti ve Tüketici Davranışları: Erzurum ili Örneği. Atatürk Üniversitesi Fen Bilimleri Enstitüsü, Tarım Ekonomisi ABD, (Doktora Tezi).

Yılmaz, V. 2009. Türkiye Akarsuları Su Kalitesi Parametrelerinin Çok Değişkenli İstatistiksel Analiz Yöntemleriyle İncelenmesi. Selçuk Üniversitesi Fen Bilimleri Enstitüsü, İnşaat Mühendisliği ABD, (Yüksek Lisans Tezi).

Yüzbaşığlu, R. ve S.N. Ataoğlu, 2018. Tüketicilerin Kekik Tüketimini Etkileyen Faktörlerin Belirlenmesi: Manisa ili Salihli ilçesi Örneği. Ağrı ibrahim Çeçen Üniversitesi Sosyal Bilimler Enstitüsü Dergisi Cilt 4, Sayı 1, s:259-270. 